RESEARCH ARTICLE

\title{
Building the Nation at the Crossroads of 'East' and 'West': Ernest Hébrard and Henri Prost in the near East
}

\author{
Kalliopi Amygdalou*
}

The transition of the Ottoman Empire into nation-states was manifested through significant state-led changes in the fabric of its urban centres, especially in cities that had a multi-cultural character and lay in debated territories. Their urban transformation was the result of practical reasons such as need for post-war reconstruction, as well as ideological factors that stemmed from a commitment to modernization and a desire to enhance and underline their national identity. Many European architects were invited to participate in the re-design of such cities. This paper explores the cases of Thessaloniki and Izmir, which after ten years of conflict found themselves on the opposite sides of the Greco-Turkish border and were destroyed by fire in 1917 and 1922 respectively. Ernest Hébrard in the first case and Henri Prost in the second, belonging to the same network of architects and coming from the same educational background, were the main architects who left their imprint on the new plans of these two cities. This paper examines the background of their involvement and their role in the design of the two cities and aims to highlight the complexity of this cultural exchange, in which the 'local' and the 'West' cannot be reduced to single definitions, and whose negotiated product became the new urban space of each city.

\section{Introduction}

Notice, nevertheless, that some cities, for example in the Orient, saw fires destroying entire neighbourhoods and that often this provided an opportunity for excellent urbanist operations.

(Danger 1947: 65) ${ }^{1}$

\footnotetext{
* The Barlett School of Architecture, UCL, United Kingdom kalliope.amyg@gmail.com
}

At the end of ten years of conflict (Balkan wars, World War I, Greco-Turkish War) Thessaloniki and Izmir found themselves on the opposite sides of the border, one in present-day northern Greece and the other in western Turkey. Both the cities were destroyed by massive fires; Thessaloniki in 1917, just five years after its incorporation into the Greek Kingdom following the Balkan wars, and Izmir in 1922, marking the end of a three-year ill-fated expedition of the Greek army into Anatolia. Their destruction was coupled with a massive demographic change, as hundreds of thousands of refugees fled the areas of conflict 
within the ten-year period, culminating in the mutual compulsory exchange of populations between the two parts in $1923^{2}$.

Both national governments, the Greek and the Turkish, invited European architects to redesign the two burnt cities; Ernest Hébrard and Thomas Mawson in the case of Thessaloniki, and Henri Prost, René Danger and his brother Raymond Danger in the case of Izmir. It was Hébrard's presence as Director of the Archaeological Service of the Army of the Orient in Thessaloniki, when the fire started, that led to his involvement in the new design. He became the chief architect of the reconstruction committee, in which two Greek architects also participated ${ }^{3}$. On the other hand, Prost was invited from Paris by the 'Society for the Reconstruction of Izmir' to carry out the new design of the burnt city (Bilsel 1996: 330-1). Still engaged with his work on the Western French Riviera, Prost recommended the surveyors-cum-urban planners René and Raymond Danger in his place. Indeed it was to them that the design was ultimately assigned, and Prost remained as a consultant, yet directly involved in the design. Izmir and Thessaloniki would later feature in Danger's 1947 teaching book Cours d'urbanisme as examples of a post-fire urban modernization.

Modernization efforts had already started in the Ottoman period, especially following the 1839 Tanzimat reforms. They were however fragmentary responses to the socio-economic changes of the time ${ }^{4}$ and did not acquire the scale, depth and symbolic meaning of the modernization projects that marked the cities' post-imperial history. It was in the nation-state era that the denomination of the 'West' as a model - as a source of solutions to empower the state and manage its new social and political challenges - and as an encompassing identity was consolidated. Reflecting the respective governments' vision for a 'modern' future, for a detachment from the Ottoman past and an inclusion into what they saw as the Western civilization, urban management acquired a scientific approach based on the philosophies of European planning schools and was accompanied by powerful institutional and legal support ${ }^{5}$.

The examined foreign architects' background and their relationship with each other is an important dimension of the reconstruction projects of the two cities, since it offers insight into the reasons they were selected and into their professional identity that would consequently influence the urban identity of the two cities ${ }^{6}$. Moreover, as we will see, the European architects carried their own opinions both about Western urbanism and the Ottoman city, which did not necessarily coincide with the views held by either the local architects (whether educated in the West or not) or the local authorities. The exploration of Hébrard and Prost's backgrounds and agency in these two projects reveals the complexity of multilateral projections of identity and of the cultural flows that took place as part of the modernization and nationalization of urban space, and helped transcend the conventional bi-polarities of 'East' and 'West'. This paper, having a tripartite structure, will first unfold the connection between these architects and its implications for the two projects. Second, it will examine the architects' relationship to the local context and last, the limits of their agency in forming the identity of the new cities.

\section{Architects, mobile and connected}

A close look at the new plans of Thessaloniki (Figure 1) and Izmir (Figure 2) will reveal important differences but also strong similarities. In both cases, the design constituted a rupture with the previous layout of the burnt zone, diffused into unburnt areas and proposed interventions in other neighbourhoods, as well as regulated the formation of new suburbs. Along with prioritizing circulation, applying land division in orthogonal plots, and laying out a network of squares and diagonal boulevards, there was also included in the design a monumental square on the 


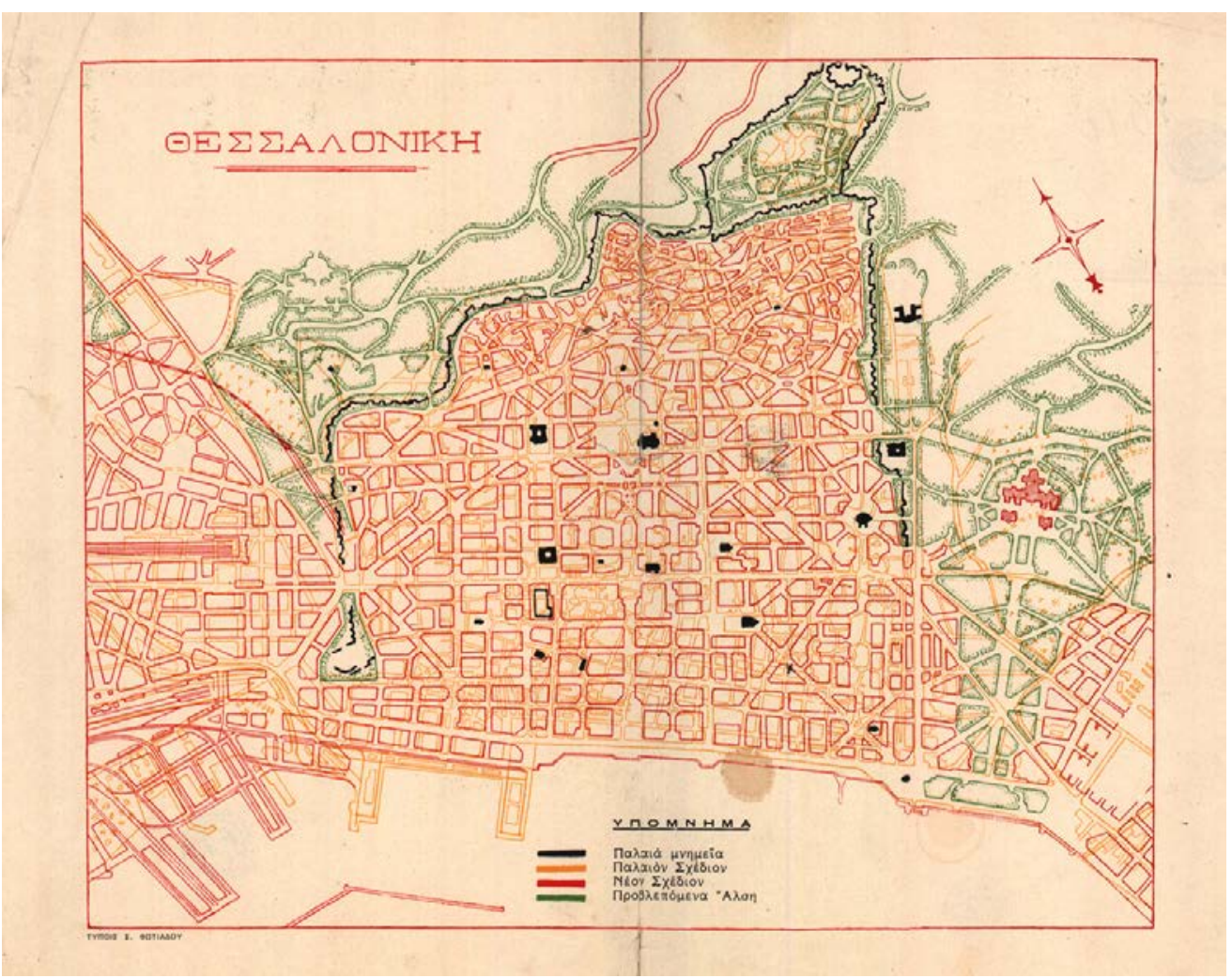

Figure 1: The new plan of Thessaloniki as drawn by the planning committee. (Thessaloniki Map Archive (Ethniki Hartothiki), 1925).

waterfront which would host a national figure (Alexander the Great in one case, Kemal Atatürk in the other). A homogenous architectural style was introduced, especially for the central axes of the city. The similarities do not restrict themselves to the visual characteristics of the urban layout, but also extend to the legal framework introduced by the state to acquire land, the prioritization of hygiene and the commercial enhancement of the centre. As a consequence of the new design, ethno-religious spatial divisions were undermined in favour of class divisions.

These similarities had to do partly with the legacy of the Ottoman Empire, its morphological and institutional characteristics, and its breakdown with the advent of nationalism and nation-building. They were also owing to the two cities' common design orientation - that of the Beaux-Arts School.
Like other urbanist schools (for example the Garden City movement and the Städtebau school) and despite their important disagreements, the Beaux-Arts architects agreed on the civilizing action of town planning and of urban aesthetics ${ }^{7}$, based on the vast ability of the city's physical setting to affect the citizen's way of life' (Hastaoglu-Martinidis 2011: 154). Consequently, they believed in the regulatory power of urbanism in the hands of public authorities. These schools' sphere of influence was consolidated not only through their considerable number of foreign students, who returned to their own countries and practiced there, but also through the activity of numerous Western European architects who took up positions and jobs all over the world.

The undertaking of urban design by Europeans in a non-Western context, colonial 


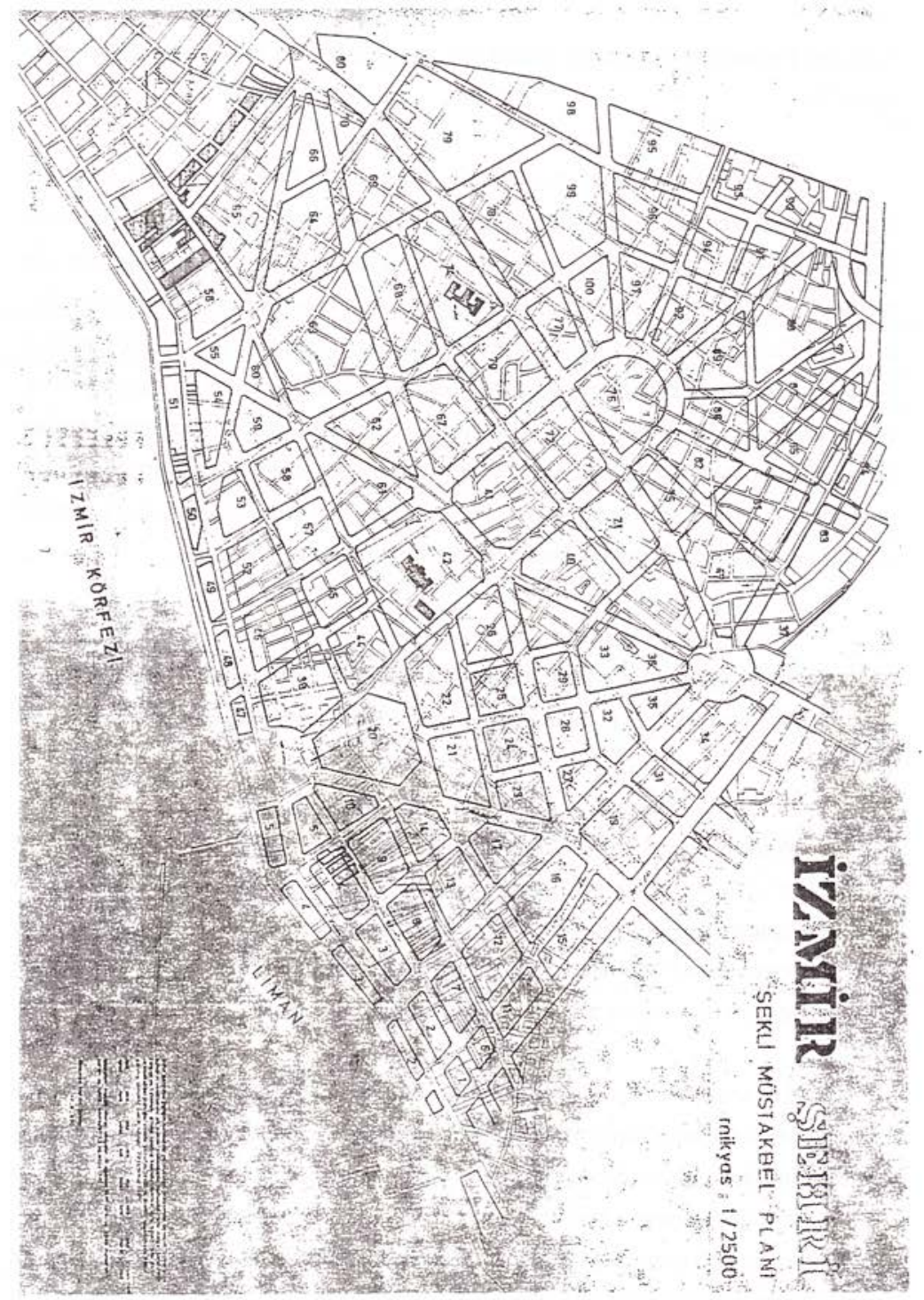

Le Plan de Réalisation élaboré par la Municipalité d'İzmir en 1930 à partir du Plan d'Aménagement Danger-Prost

(Le futur tracé de l'aménagement est superposé sur l'ancienne trame de la partie incendiée)

Figure 2: The new Plan of Izmir as approved by the Municipality in 1930, based on the Danger-Prost plan. (Bilsel 1996: 337). 


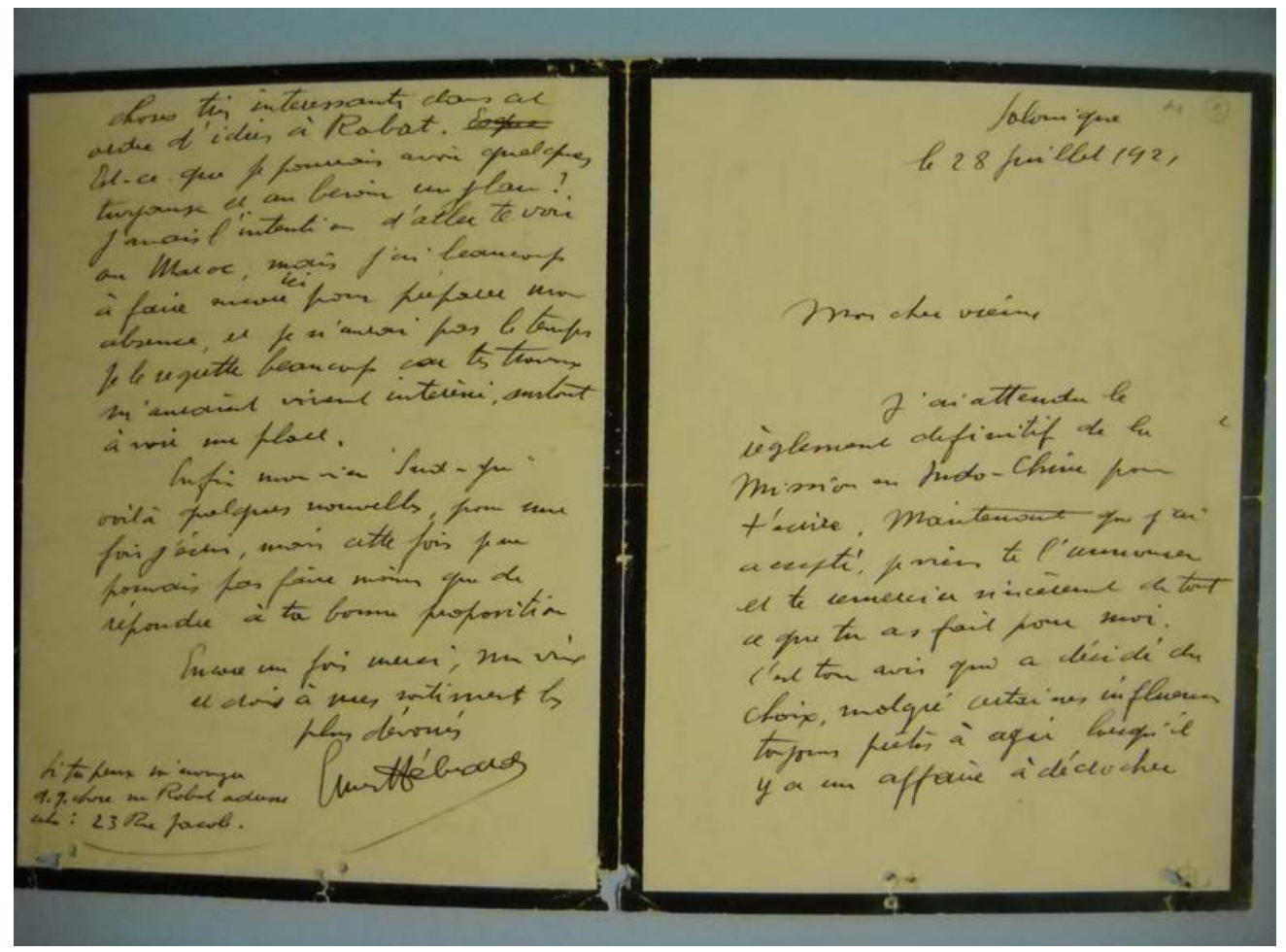

Figure 3: Letter from Ernest Hebrard to Henri Prost. (Fonds Prost, Archives s'Architecture du XXe siècle, Paris, 1921).

or otherwise, was widespread ${ }^{8}$, but what is most interesting in our case is the relationship between them. In a letter dated 28 July 1921 sent from Hébrard to Prost while he was in Thessaloniki (Figure 3 translated in Appendix 1$)^{9}$, Hébrard thanks his 'old friend' (mon vieux), as he calls him, for having a decisive role in him being assigned an important new project. (For the translation of the letter by the author see Appendix.)

Henri Prost, in contact with the French General Governor in Indochina, Mr. Long, proposed Hébrard (based in Thessaloniki at the time) for a six-month job to create an important station in Daalat, French Indochina. At the same time (in the same postal dispatch) he also wrote to Léon Jausselly ${ }^{10}$, explaining that he did not propose him for the job as he knew how busy he was in Paris, and asking him to find a replacement if Hébrard did not accept. Hébrard accepted and moved to Hanoi in 1921. He ended up spending ten years planning several towns in Vietnam, Cambodia and Laos (Figure 4, lower graph).

Prost himself could not take the job in Indochina because, at the time, he had just returned to France and was working on the Western French Riviera (Cote Varoise). He had been in Morocco from 1914 to 1924, in the service of Maréchal Lyautey, then governor of Morocco, designing the cities of Rabat, Casablanca, Fez, and others. His next stop would be Izmir; later, as it is well known, Prost would preside over the master planning of Istanbul (Pinon and Bilsel 2010). It has been suggested that Maréchal Lyautey was the one who introduced Prost to Mustafa Kemal Atatürk, founder of the Republic of Turkey and its first President. Lyautey was in contact with Mustafa Kemal ${ }^{11}$ through a French journalist, Berthe G. Gaulis, who was a supporter of the Turkish side and the Ankara government during and after the Turkish Independence War (Güven 2006). 

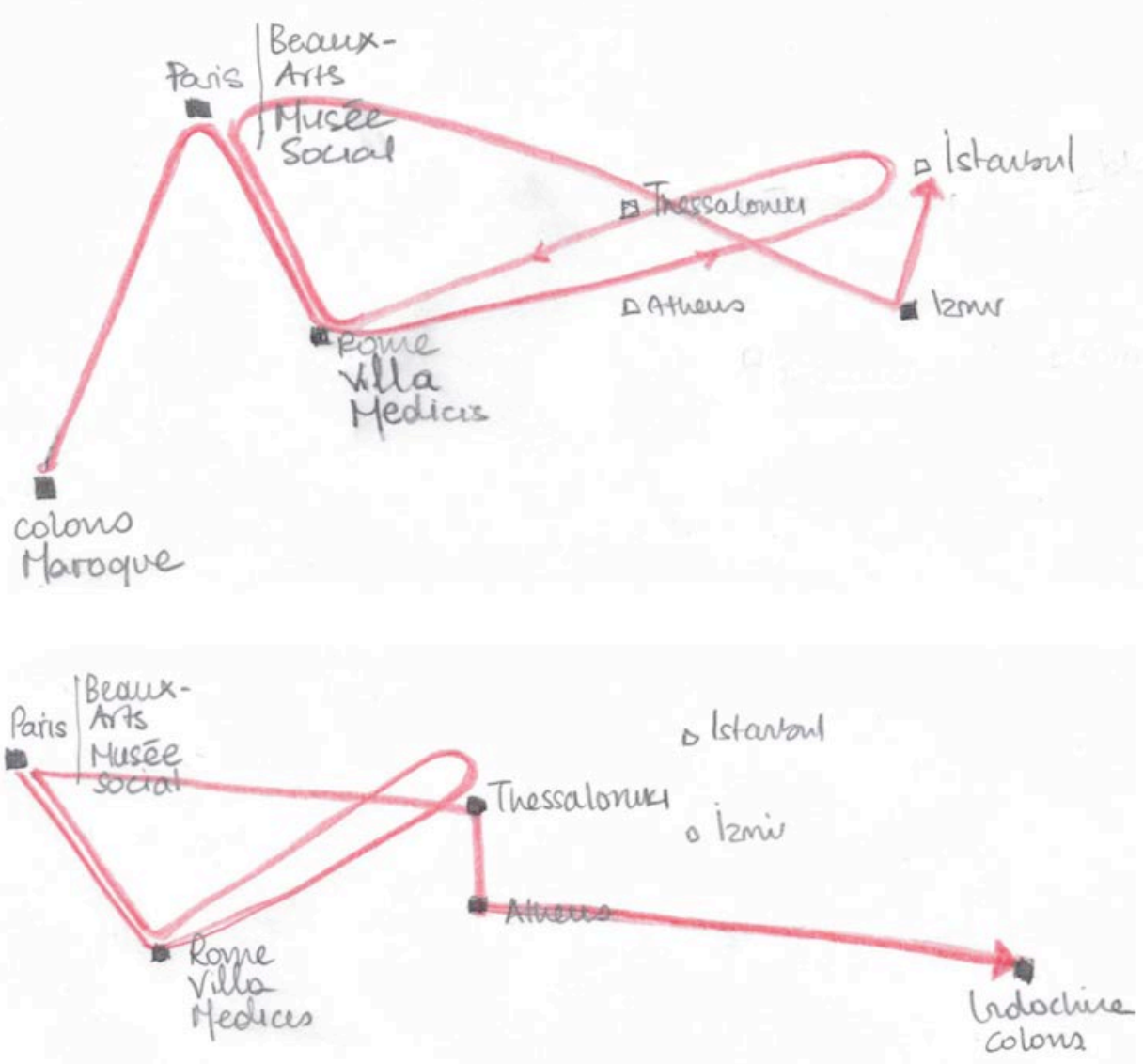

Figure 4: Diagram depicting the professional/academic journeys of Henri Prost (above) and Érnest Hébrard (below). Rendition by the author.

The mobility depicted above indicates only parts of the extensive network of architects and political actors of the day and how they related, competed, and divided the jobs worldwide, not very differently from today. But what were the foundations of the relations that connected Ernest Hébrard and Henri Prost? What lay behind the letter's opening words 'My old friend'?

Both studied at the École des Beaux Arts and during their studies there, both won the Grand Prix de Rome and moved to Villa Medici, where the Académie de France in Rome was situated. Prost won this prestigious award in 1902. He found in Rome, Tony Garnier, already in his 3rd year, working on the Cite Industrielle, and Paul Bigot, in his 2nd year, working on the reconstitution of a cast section of 4th century Rome. Just one year ahead of Prost, Jean Hulot was working on the reconstruction of Selinus. The shift from working on singular monuments or buildings to exploring the urban dimension had already taken place when Prost arrived in Rome, and he was openly inspired by the other scholars' 'important projects of an unforeseen character which hadn't been addressed until then' (author translation from Prost's correspondence). ${ }^{12}$

In the following year, Léon Jausselly was added to the group, having won the Grand Prix de Rome of 1903. He started working on the city of Pompei and shortly afterwards won the competition for the master plan of Barcelona and moved there. In 1904 Ernest Hébrard became the latest addition to this 
elite group of architects, and chose to study the Palace complex of Diocletien in Splalato, in today's Croatia.

As Hautecoeur (1960: 11-30) also mentions, Prost was influenced by the interest in urbanism he found during his stay at the Villa Medici and he travelled to Istanbul, where he studied not only the church of Saint Sophia itself, but also the whole urban complex surrounding it. In fact, it was this decision to study Saint Sophia within the context of the Grand Prix de Rome and to live in Istanbul for two years that determined his future career. In March 1912 he was told by Georges Risler (president of the Musée Social) in a casual encounter (author translation from Prost's personal notes):

Prost! You have to leave for Morocco! I saw General Lyautey...HE IS AN EXTRAORDINARY MAN; He wants to create new cities - you, a person that knows well the Muslim customs [moeurs musulmanes], you will work there without difficulty- go! ${ }^{13}$

The experience of Istanbul, coupled with his Morocco experience, made him Ataturk's choice for Istanbul in the 1930s. As the newspaper Le Figaro wrote in August 1938, he has (author translation from Le Figaro 19 August 1938),

a deep knowledge of Constantinople, where, during his training at the Villa Medici, he stayed for two years, working in Saint Sophia...and the experience of cities where two civilizations compete each other, tolerate each other or are in harmony, an experience acquired next to Maréchal Lyautey. ${ }^{14}$

Moreover, Prost and Hébrard were involved along with many important French architects of the time in the Musée Social, which, according to Ipek Akpinar (2003: 59), with its principles in modern planning (functional zoning and hygiene) might be interpreted as a pre-step in the formation of ClAM in the 1930s.' Prost and Jaussely also co-founded the Société Française des Urbanistes in 1911 together with Donat Alfred Agache, Marcel Auburtin, André Bérard, Eugène Hénard and others, while Prost co-edited the journal Urbanisme together with Jean Royer.

In his 1921 letter, Hébrard further informed Prost that his position hadn't changed despite the change of government in Greece in November 1920, and that the plan of Thessaloniki was almost ready; it was now a question of application in space, something that could be done during his absence. Apart from their common educational and ideological background and their belonging to the same professional circles, we see that Prost knew about Hébrard's work in Thessaloniki. Meanwhile, urban historian Pierre Lavedan had written about Salonica (Thessaloniki) in the Gazette des Beaux Arts already in 1921, while Léon Jaussely used the example of Thessaloniki when teaching at the École des Hautes Études Urbaines (1919-23). We can be almost certain, then, that not only Prost was fully aware of the reconstruction of a very similar city in the region by his old friend, but also that this project had already entered bibliography as a successful example. This could suggest that there is an interactive influence between the two cities.

The consideration of these international networks of architects and their common background helps realize the weight of the urbanist ideas carried by the architects into the design of the two cities. At the same time, it helps position the case studies within a wider context rather than treating them as isolated bi-lateral interactions between a 'nonwestern' and a 'western' point of reference.

\section{Encounters with the 'East': Hébrard and Prost's relationship with the Near Orient}

The urbanist tradition that Hébrard and Prost came from did have a universal character but was also very much concerned with local heritage. So what was the relation of Hébrard and Prost to the local context they were invited to transform? One can safely 


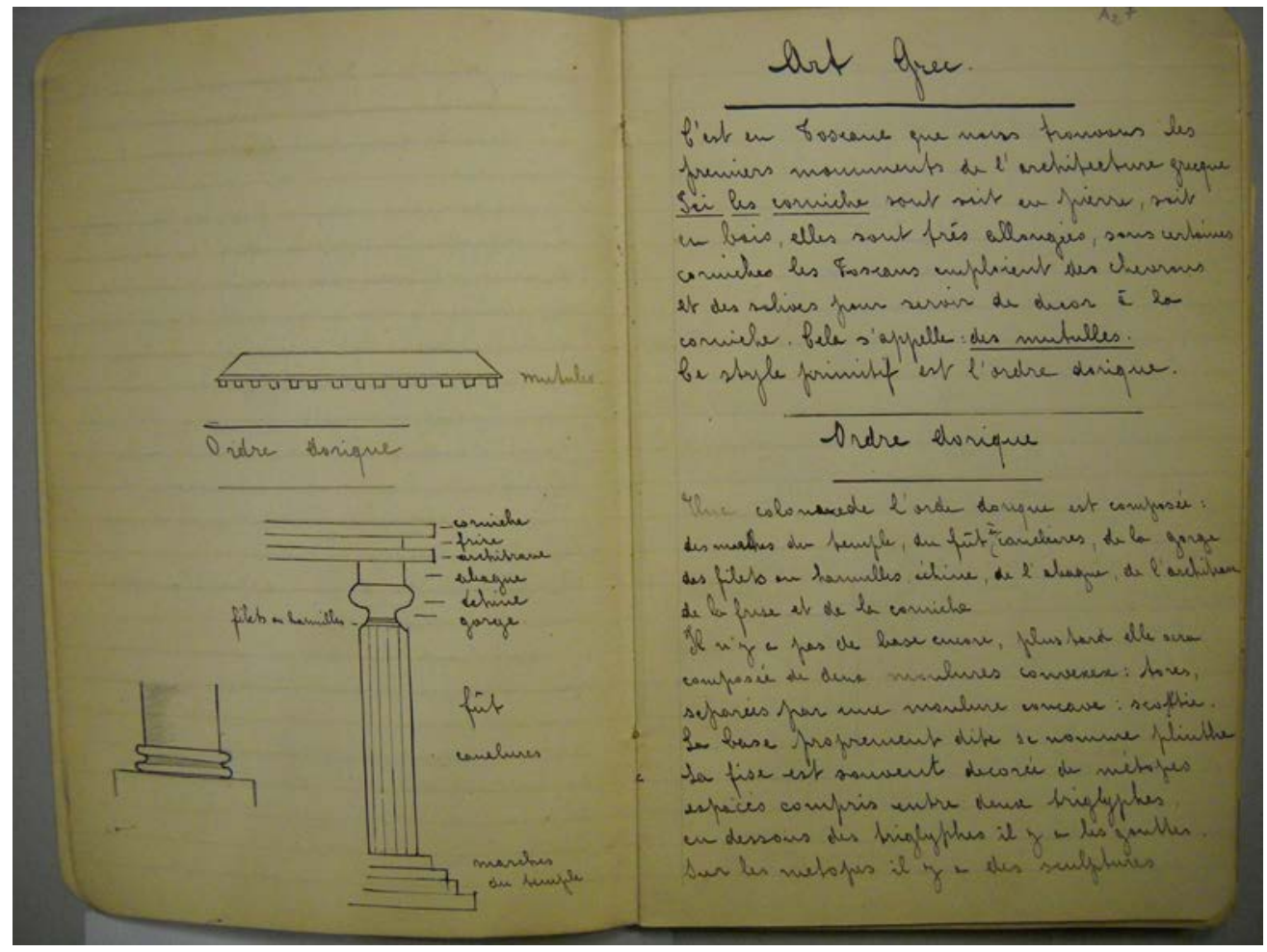

Figure 5: Henri Prost's notebook for the class 'Résumé des Beaux-Arts' by Suzanne Vent. (Cité de l'Architecture et du Patrimoine, Archives d'Architecture du XXe Siecle, Fonds Henri Prost, 1896).

assume that they were familiar with at least some of the publications on Greece and Anatolia relating to archaeological findings and Greco-Roman architecture, as well as with travellers' memoirs from the 'Orient'. However, in addition to the above, it is to be noted that they had received an education that located the foundations of architectural aesthetics in ancient Greco-Roman architecture (Figure 5), as can be observed in Prost's notes.

Their professional formation all too often involved a Voyage d'Orient for the familiarization of the young architects with these roots, like we saw in the case of the Villa Medici. Hébrard travelled with Prost to Istanbul in his first year, while Prost also traveled to Konya and Greece with Jean Hulot. Hébrard travelled to the Balkans and worked on the archaeological site of Diocletian's Palace in Split together with J. Zeiller. In their travels and studies of archaeological sites like Selinus and Priene, they expressed their appreciation of the rationality of the Hippodameian system and its orthogonal division of plots. They sent back to the Beaux Arts drawings of extraordinary detail (Figure 6).

I argue that when the architects were invited to redesign Izmir and Thessaloniki, they had a different approach to local architectural heritage from when building in Morocco or Indochina; they considered it to be part of their heritage as well as that of the West. However, this appreciation did not necessarily match the way they saw the inhabitants of these cities. Referring to the newly designed streets of Thessaloniki, the historian Lavedan writes:

Some, like Venizelos Street and Alexander the Great street, bordered by archades under which luxury shops 


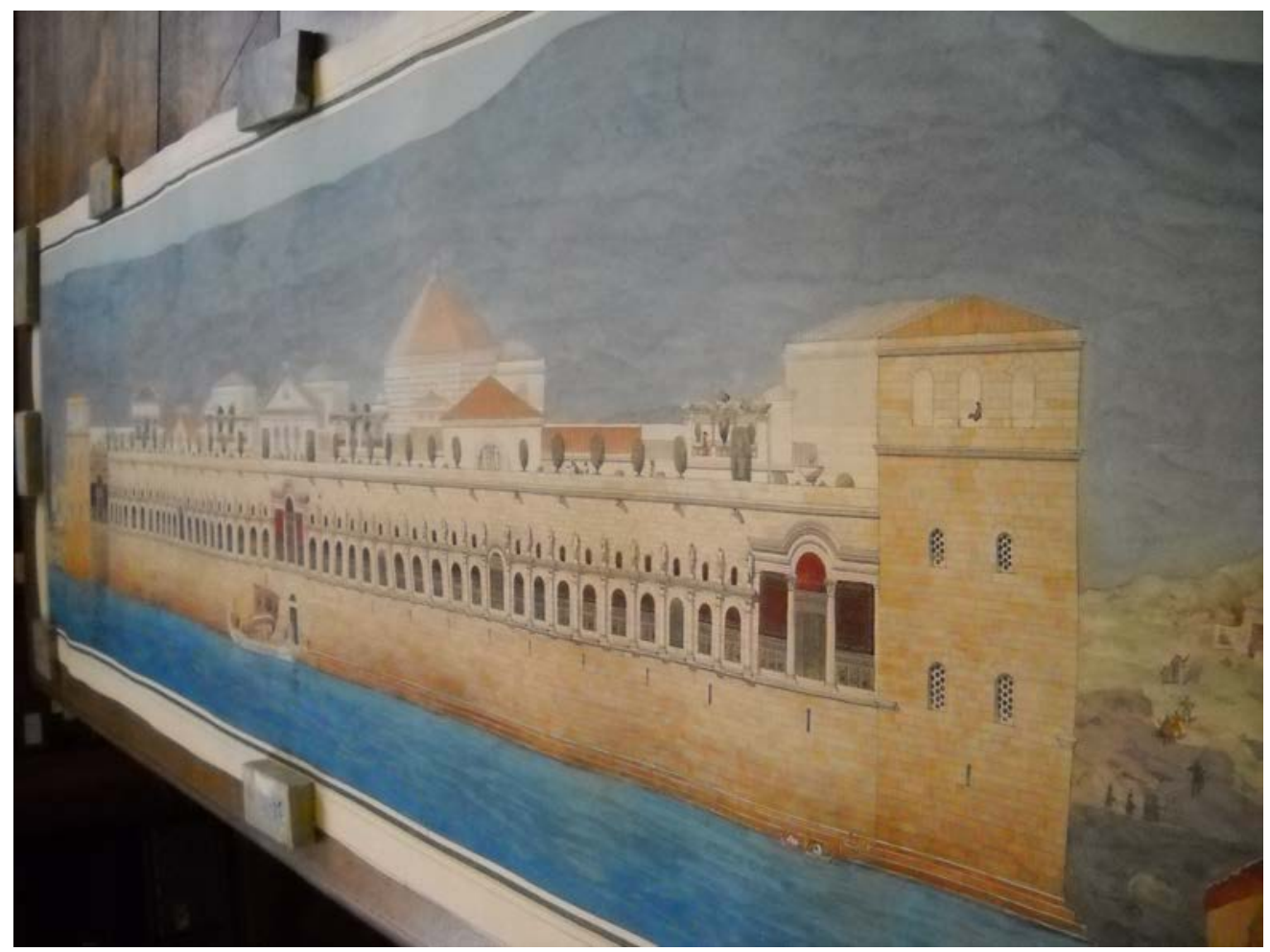

Figure 6: Ernest Hébrard, drawing of the Palace of Diocletien, in Split. (École Nationale Superieure des Beaux Arts, Paris).

were opened, had a restricted width: the pedestrians should be able to stroll (flâner) and move easily from one pavement to the other. Don't forget that in the Orient even the least of purchases can be the object of very long discussions and that time has little value (Lavedan 1933: 152-3).

Such an attitude was also fuelled by the quest for legitimacy of French presence in the area. Stamatopoulos (2009: 68) has demonstrated in his book Byzantium after the Nation how the Greek irredentionist 'Megali Idea' 15 was a reaction to French intervention in the Ottoman Empire and to the aspiration of France to set foot on those lands. Historian and journalist Jean-Joseph Francois Poujoulat, in his pamphlet 'La France et La Russie a Constantinople' of the mid-nineteenth century, advocated that the 'peoples of the Ottoman Empire can move towards the West only if the French nation (and the Catholic Church instead of Russian or Greek Orthodoxy) not only mediate but install themselves in the East' ${ }^{\prime 16}$.

The architects' educational connection to the Greco-Roman roots does not restrict itself to drawings and to sending back surveys to the École des Beaux Arts. As I briefly mentioned in the introduction, the reason why Hébrard was selected to redesign Thessaloniki was that at the time of the fire he was already there. He was conscripted to the Army of the Orient that arrived in Thessaloniki in late 1916, as part of the military Archaeological Service. The competing British Archaeological Service was also there. The archaeological service that was set up had identified by 1919 more than 70 protohistoric sites in the area, conducted numerous excavations, collected the findings and displayed them to the troops. Many of the findings were shipped to the West (Mazower 2004: 317) ${ }^{17}$. 
But this is only one side of the story. Similar excavations happened in Izmir, and the two states were very eager to include Westerners in them. As Davis $(2000,2003)$ has demonstrated, archaeological excavations involving Westerners in the newly acquired territories were a matter of gaining legitimacy over the land. The presence of Western archaeologists, representatives of powerful institutions and with connections to their respective governments, was a matter of tactic, as they often signed papers of permission for excavations hence indirectly recognizing the new authorities' presence in that territory. Could we not introduce this dimension to our study of the reconstruction of the two cities? Is it not possible that the undertaking of the reconstruction of the city by Western, renowned architects, confirms the authority of the new owners of the cities, somewhat like an international peace treaty?

\section{Politics of Heritage}

How did Hébrard and Prost's views of Thessaloniki's and Izmir's cultural identity manifest themselves in the design process? This question is directly related to the issue of agency of the various spatial actors involved - how powerful were the European architects, invited because of their status of authority, in the decision-making?

Contemporary research on peripheral modernities and hybridity (Akçan 2012, Isenstadt and Rizvi 2008) has criticized earlier Eurocentric accounts that constructed non-Western countries as passive receivers of European modernism. It has revealed the complexity of interactions across geographies and brought into focus the dimension of power and agency, and processes of crosspollination and interpretation.

On the one hand, planners, architects and authorities were not totally devoid of a colonial or imperial imagination. They were convinced that they were playing a benevolent but paternalist role in civilizing backward populations. However, they had fundamental disagreements about the importance of the history and culture where they applied the 'universal' values of urbanism. All the agents involved - politicians, architects, intellectuals and users - had a variety of ideas on what 'modernity' was, what the 'topos', the local geography, was, to what extent these two were different, complementary or contradictory and to what extent they should be adjusted with each other. The designs proposed by the French planners were not a simple application of an international urbanist formula, but were a result of mutual constructions of the 'west' and the 'local' and a product of negotiation. Within the limits of this paper, I will examine only one of these important fields of negotiations - the preservation and projection of heritage in order to reflect the cultural identity of each city.

One of the first steps Henri Prost took when he started working on Izmir was to document, in detail, the burnt area. Prost believed in the preservation of important architectural heritage and was eager to include any saved or repairable buildings in the new plan. In the map below (Figure 7) we can see, for example, the notable surviving public buildings in red - 'Hopital Francais, reparable', 'Ecole', etc. - and the religious monuments in purple - 'cathedrale solide' (cathedral, solid), 'Chapelle Protestreparable', 'Ecole St Joseph-incendiee' (School St Joseph-burnt), 'Eglise reparable' (repairable church), etc. Ten years later, when composing the plan of Istanbul, his biggest work, Prost's appreciation of historical sites, which he thought of as 'a universal cultural heritage', was even more manifest. He wrote, "the preservation of the antique remains in the open air museum will show the sensitivity of the Turkish administration towards the works of art from the past' (Akpinar 2003: 83).

In Izmir, he also tried to preserve Frenk Caddesi, the trace of a crooked commercial old street running though the old centre, a strong symbolic representation of the European Quarter (Figure 8). 


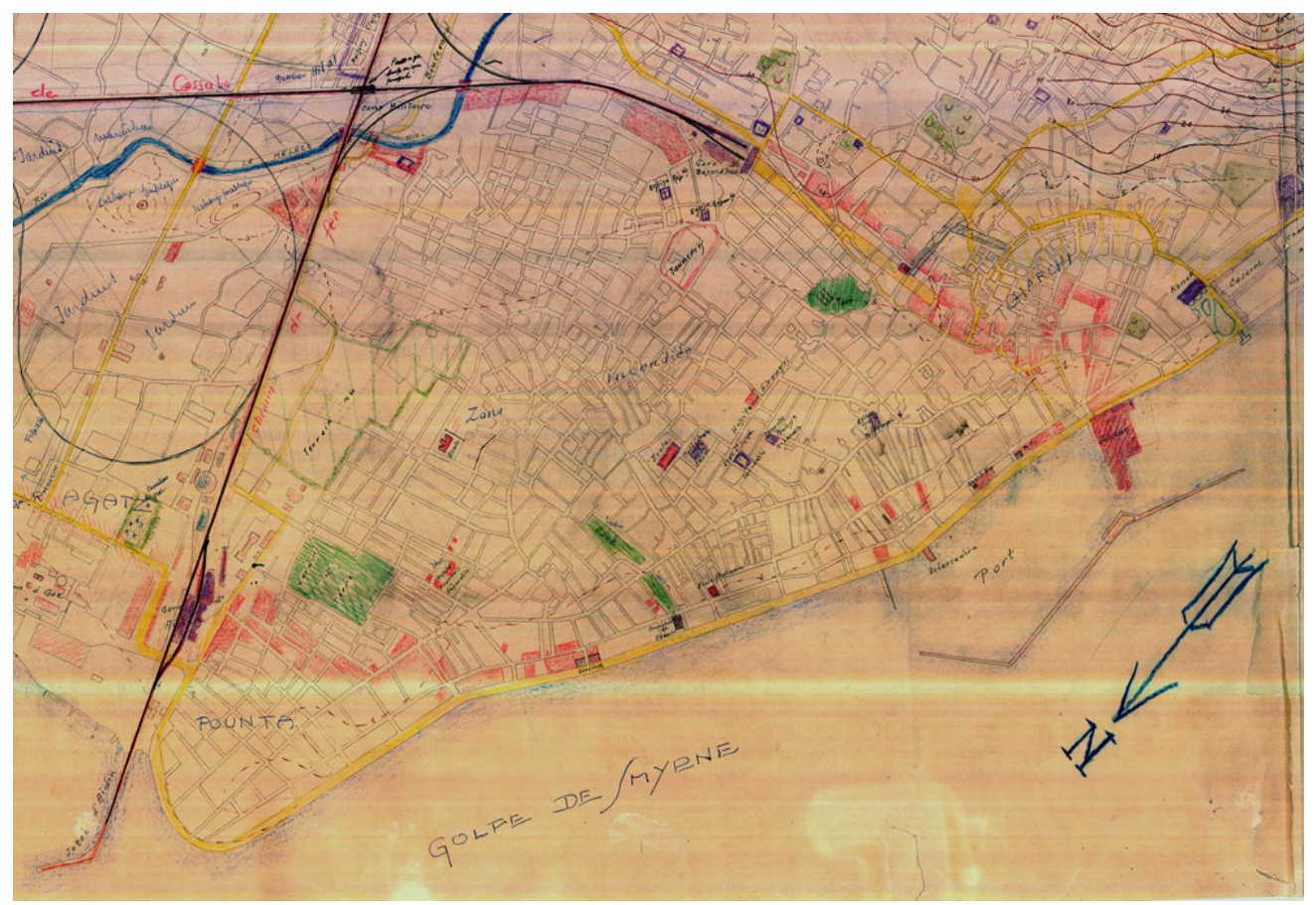

Figure 7: Izmir's burnt area map with H. Prost's notes. (Cité de l'Architecture et du Patrimoine, Archives d'Architecture du XXe Siecle, Fonds Henri Prost, ca 1924).

His approach to conservation did not please the mayor of the city, Behcet Uz, who later stated (translation by author from French),

The points of view of Prost are not realizable for Izmir in some aspects. The city of Izmir is absolutely not accordant with the preservation of whatever monuments as decoration in the middle of the streets. But it is ready to value a work of Architect Sinan, if it finds one, by creating parks around it. In any case there are monuments that we have saved by this way. By doing this plan, we are advancing while thinking of the comfort of the generation of the next fifty years ${ }^{18}$.

The government's admiration of French urbanism and its invitation of Henri Prost and the Danger office to design the city did not imply its uncontested acceptance. The concept of memory and 'monument', so established and respected in the French School, was irrelevant to the municipality of Izmir, which aspired to build a new modern city according to the new principles of Turkishness.

On the other hand it is also appropriate to question Prost's intentions in trying to preserve the multiculturalism of the city. Was he trying to protect a universal heritage, or the remains of the city's western identity, or - taking possibly a long shot - was he applying in space, methods of association with the deemed 'other' like the ones used in the colonies? ${ }^{19}$ In his sketches for the new city of Izmir (Figure 9), can we possibly trace the arched colonnades of the colonial city next to the rationalist approach to street design? Was it the metropolis or the colonial city that Prost had in mind when designing? ${ }^{20}$

Similarly, in their rejection of Prost's style of approach and the preservation of any nonMuslim or indeed Ottoman monuments, was it the metropolis or the colonial city that the Turkish authorities had in mind while 


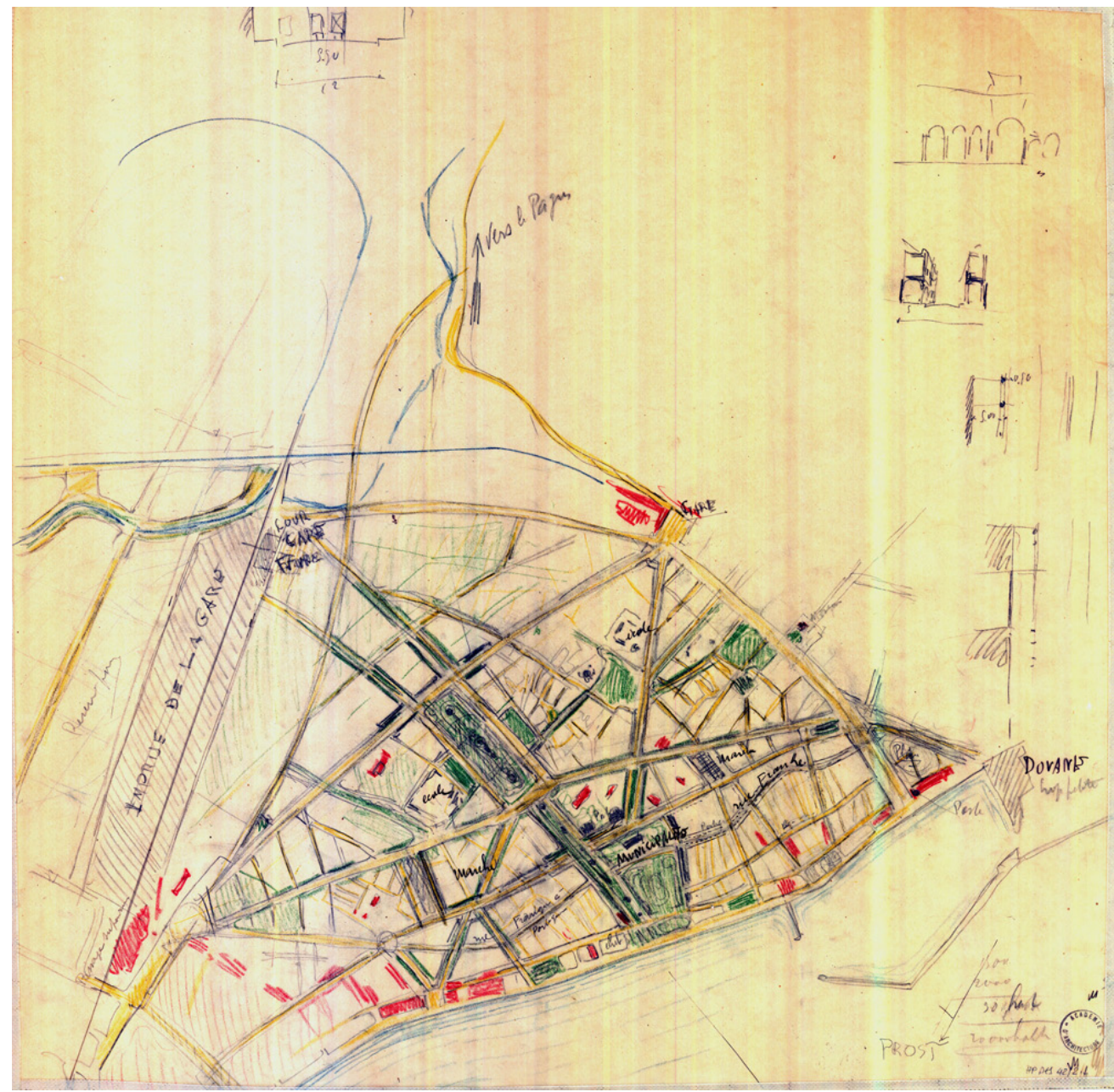

Figure 8: H. Prost's sketch plan for the new city of Izmir. (Cité de l'Architecture et du Patrimoine, Archives d'Architecture du XXe Siecle, Fonds Henri Prost, ca 1924).

inviting Prost? Which 'modernity' did the politicians and the planners envision in their own conceptions of the urban?

Meanwhile in Thessaloniki, instead of a relative amnesia, a selective memory approach was followed. Following the theory of continuity ${ }^{21}$, which advocated linking of modern Greeks to the ancient Greeks through the mediation of Byzantium, the new plan restored the Hippodamian system of the Hellenistic city and accommodated modern traffic by introducing diagonal routes, while directing visibility to the most prominent Byzantine monuments.
A uniform architectural style for the buildings lining the boulevards was imposed, conceived as a reference to the city's Byzantine past, though its resemblance to colonial architecture that applied to that period in northern Africa is remarkable. (HastaogluMartinidis 2011: 164)

According to Yerolympos (2013), thanks to Hebrard's initiative, some Ottoman monuments were conserved, even though they did not acquire an important position in the new city layout. Many Ottoman buildings suffered 

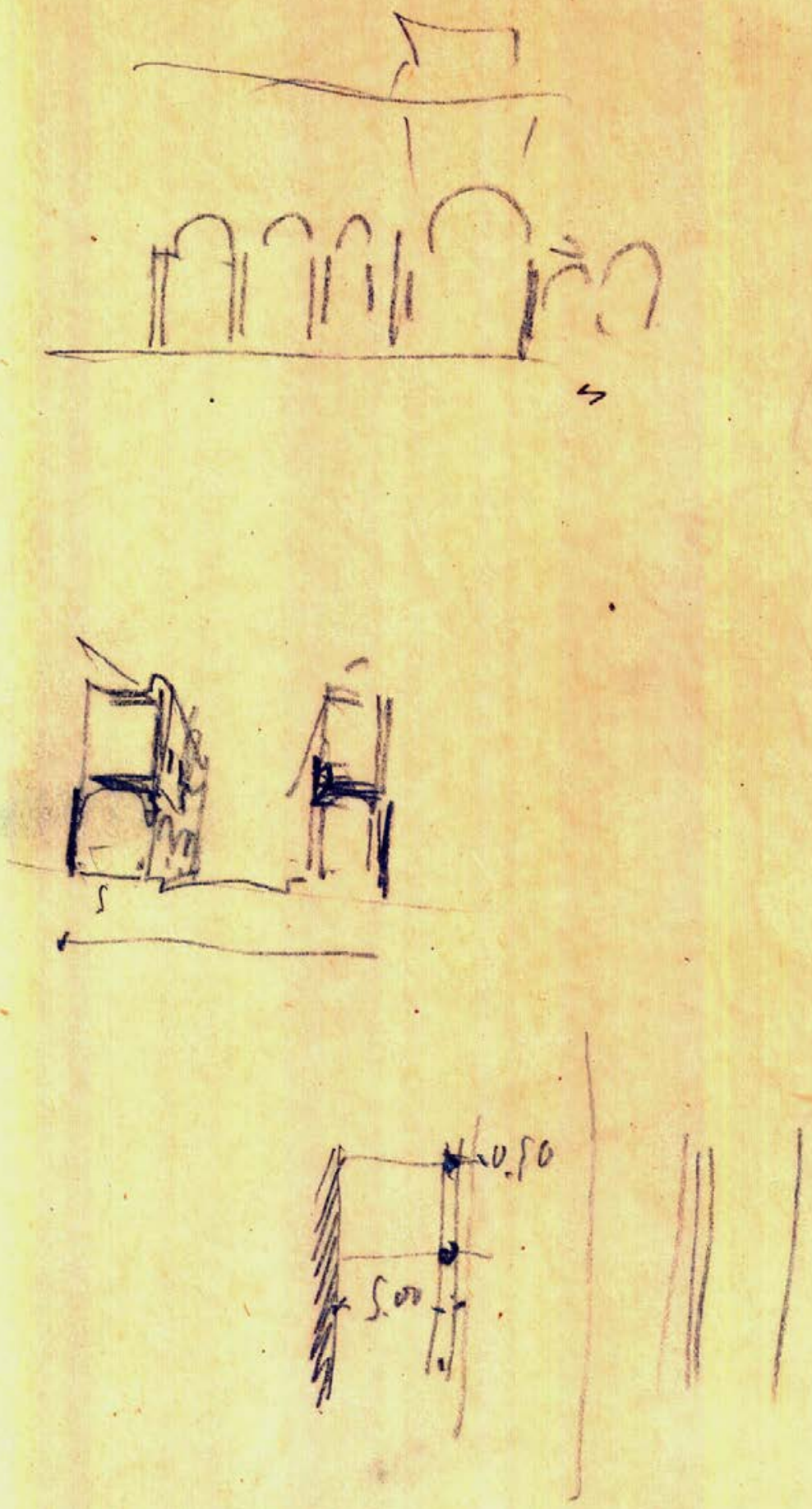

Figure 9: H. Prost's sketch plan for the new city of Izmir, detail. (Cité de l'Architecture et du Patrimoine, Archives d'Architecture du XXe Siecle, Fonds Henri Prost, year ca. 1924). 
from devaluation, as they were considered to be remnant symbols of a barbaric foreign rule. The baths next to the White Tower and one bathhouse by the Modiano Passage were demolished, while the covered market, called Bedesten, survived only because of the persistence of the urban planners.

This discrimination against the Ottoman heritage intensified after the departure of the last Muslims in 1924. The municipality decided almost immediately to demolish the city's minarets, which had been the defining feature of Thessaloniki's skyline, and invited building companies to bid for the work, causing the harsh criticism of the former prime minister, Alexander Papanastasiou ${ }^{22}$.

The cases of Thessaloniki and Izmir reveal the empowered engagement of local and central authorities in the project of their urban modernity. Multiple revisions of the plans, which are not explored within the limits of this paper, also testify to the authorities' eagerness in closely determining the form of the cities. Although the architects and the authorities shared a desire for the cities to be 'modern', which lead them to appreciate a Beaux-Arts School urban layout, the role of monuments in such an urban modernity could not be agreed upon. Rather, different actors re-read and re-wrote modernity, becoming authors of a new 'text' addressed to their intended audiences. Based on their claims to legitimacy, nationalist selfdetermination, economic priorities, political ideology and technological limitations, local actors negotiated with the European architects in the process of creating a modern and national identity for their cities.

\section{Conclusion}

The examination of Hébrard and Prost's background and their connections to each other highlights an important dimension of the architectural transition from the imperial to the post-imperial city that is the subjection of some of its variables to both the institutional formation of its actors, their personal life stories and their professional connections. The case studies emerge as pieces of a complex landscape defined by the mobility of people, information and ideas owing to and extending beyond the political, economic and institutional changes dictated by the collapse of the Empire and the rise of the nation-state

The French architects involved did not have abstract or uniform conceptions of one singular 'East', but their ideas were rather based on a combination of their tangible experience (gained from their travels), their architectural education, their professional experience in the colonies and their own national formation, which connects them to the Greco-Roman heritage. This relationship to the local context informs their suggestions with regards to the treatment of local heritage, a question in any case valued by the Beaux Arts tradition.

However the significance of the examined international architectural networks and the desire of the new nation-states for modernization did not lead to a direct implantation of an uncompromised 'Western modernity' into a receptive local context. The actors involved in the reconstruction - local and foreign, politicians and architects - had different agendas and different understandings of how the relationship to the West and to the nation's past should be articulated. These different approaches were not dictated by geographical categories; it was not necessarily the French architects who advocated the imposition of a clear 'Western', or 'colonial' model, and it was not necessarily the local politicians who were protective of their local heritage. Rather, we can witness a variety of interpretations of the 'West', 'us' and the 'other', dictated by the needs of power, identity and legitimacy, particularly with respect to land. The negotiation between these different positions conditioned the degrees and ways of incorporation of the architectural heritage into the canon of national representation. The relationship to the West, and the relationship to the 'nation's' past which was also determined by the need to belong to the 
West, emerge thus as the two basic constituents of the identity equation and of the quest for legitimacy.

\section{Appendix 1}

Letter from Ernest Hebrard to Henri Prost, 1921, Fonds Prost, Archives s'Architecture du XXe siècle, Paris. Translation by the author the areas marked as "----' were illegible.

'My old friend,

I waited for the definitive decision regarding the Indochina mission in order to write to you. Now that I have accepted, I proceed to announce it to you and to thank you for all that you have done for me. It is your opinion that was decisive for my selection despite certain always existing pressures, whenever there is an affair to solve.

You see that this affair took some time. In the beginning I hesitated and upon receiving the letter I didn't want to accept [the job], especially since, despite everything one could say or write about my case, my status [in Thessaloniki] remains the same as before the change of the Greek government. But upon reflection I allowed myself to be tempted by the magnificent trip and the prospective interesting work.

The new plan of Salonique is ---- ready (It has been carried out to a sufficient extent in order not to ---- changes) it is just a question of application and I can certainly be absent. There are still [issues with] the public monuments- the Post Office is ready but there is no money. It is the same for the plan of Athensthe war absorbs everything.

When, a couple of days ago, I suggested taking a leave for six months, the ---- was deplorable, the minister begged me to stay but facing my resistence he asked me to return [in the future] and [said that] my position would be conserved. It is all I was asking for because Salonique interests me a lot and I want to continue working on it. [...]

So everything has been arranged for the best and on September 6th I will take the boat for the Far East. As you know it is about drawing a city in Dalat. It will be a pleasant city in a beautiful country where the climate is ideal. According to what I have been told, you have created very interesting things along this kind of ideas in Rabat. [...]. I had the intention to come and see you in Morocco, but i still have a lot to do here in order to prepare for my absence and I don't have time.

I regret it a lot because your projects interested me very much, especially to see them on site.

Finally ----. So here is some news, for once I wrote to you, but this time I couldn't do less than respond to your good proposition.

Once again thank you my old friend, and accept my most devoted feelings.

Ernest Hébrard

\section{Acknowledgements}

I owe special thanks to Dr. Jan K. Birksted from the Bartlett School of Architecture, UCL, for his valuable comments. I would also like to thank Prof. Alexandra Yerolympos for her suggestions and our discussions in Thessaloniki; Ioanna Basta for giving me a home in Paris; and Irem Yaylalı Gençer for her help in my archival research. I am grateful to the A. S. Onassis Public Benefit Foundation and to the Foundation for Education and European European Culture (IPEP) for funding my doctoral studies.

\section{Author Information}

Kalliope Amygdalou is a Ph.D. Candidate in Architectural History and Theory at The Bartlett School of Architecture, University College London.

\section{Notes}

${ }^{1}$ Danger, Réne 1947, Cours d'Urbanisme, Editions Eyrolles, Paris, p. 65 (Translation by the author). The first edition was published in 1939. The book was used as teaching material for a course on urbanism taught by René Danger at the École Spéciale de Traveaux Publics in Paris.

2 As decided by the Lausanne Treaty signed in 1923, 1.5 million Greek Orthodox people were forced to leave Turkey and 
move to Greece, while 500,000 Muslims were forced to move from Greece to Turkey. 117,000 refugees settled in Thessaloniki alone. As these populations were assigned new homes in the receiving countries, they were asked to assimilate and to enhance the new national character of their surroundings; the Greek profile of Thessaloniki and the Turkish profile of Izmir respectively.

${ }^{3}$ The design committee also included the engineer Joseph Pleyber and two Greek architects, Aristotelis Zahos and Konstantinos Kitsikis.

${ }^{4}$ Such were infrastructure projects (ports, quays, train stations), localized post-fire redevelopment of specific neighbourhoods in a more orderly manner, demolition of city-walls and urban expansion beyond the historic centre (See Yerolympos 2013, Kolluoglu Kırli 2007: 218).

${ }^{5}$ For a very detailed analysis of the reconstruction of Thessaloniki, including the legal and institutional changes introduced, see Yerolympos (1995, 2013). See also Hastaoglu-Martinidis (2011) and Kolonas (2012). For the case of Izmir see Bilsel (1996) and Baran (2009). Thessaloniki and Izmir were not unique in their transformation as part of nation building. Notable examples were Sarajevo (annexed by the Austro-Hungarian Empire in 1908), Alexandria in the 1920s and 1930s and Sofia after the independence of Bulgaria in 1878 (Yerolympos 1996, Hastaoglu Martinidis 2011).

${ }^{6}$ Within the limits of this paper the background of the other European professionals involved in the two reconstruction projects, namely René and Raymond Danger in Izmir and Thomas Mawson and Joseph Pleyber in Thessaloniki will not be explored. Since Hébrard and Prost are attributed with having the primary role in the two designs, their cases are most appropriate in order to explore the threads connecting two projects in two different national contexts hostile two each other.

${ }^{7}$ Hébrard together with Hendrik Christian Andersen had also conceived and designed the 'World Center of Communication' in 1912. This utopian city was based on the belief that Beaux-Arts architecture could bring about world peace and international harmony (Wright and Rabinow 1982). Meanwhile, after the First Town Planning Conference organized by the Royal Institute of British Architects in London in 1910 and attended by the most influential planners of the time, the interaction and exchange of European and American experiences intensified (Yerolympos 1995, Lemes 2010).

${ }^{8}$ In our case, the context is not colonial but it is nevertheless the context of peripheral nation-building, in which the great players of the time, especially France, England, Germany and Russia, were intervening directly. Hundreds of foreign professors and engineers were invited to taking part in the setting up of the Turkish Republic. See Akpinar (2003: 47), Akçan (2012), Bozdoğan (2001).

${ }^{9}$ Centre d'Archives du XX siecle, Paris.

${ }^{10}$ Architect and urban planner, who designed a master plan for Barcelona.

11 The Letter from Mustafa Kemal to Maréchal Lyautey, dated 23 December 1921, is mentioned in Bilsel (1996: 332). This suggests that the Society for the Reconstruction of Izmir might have got directions from Ankara when contacting Prost.

12 Communication à l'Académie des BeauxArts - La Villa Medicis et L'Urbanisme taped on January 18th 1959, Archives du XX Siecle, Paris. Translation by the author.

${ }^{13}$ Communication à l'Académie des BeauxArts - La Villa Medicis et L'Urbanisme -taped on January 18th 1959, Archives du XX Siecle, Paris. Translation by the author. Formatting of the text is from the original.

${ }^{14}$ Le Figaro (Monday 19 August 1938), Archives du XX Siecle, Paris. Translation 
by the author.

${ }^{15}$ Megali Idea, meaning 'Great Idea', was the name of the mid-19th century-early 20th century expansionist ideology that aimed to incorporate into the Greek Kingdom all the lands with historical Greek presence.

${ }^{16}$ In the treaty of Sevres, France was given Syria and the neighbouring parts of Southeastern Anatolia, while large areas up to Sivas and Tokat were declared a zone of French influence.

17 '...strict orders came from London that holdings in British hands were to be shipped back to England. The Greeks were outraged but could do nothing about it as they were hoping to tap the British and French for loans and longterm investment funds to rebuild their new territories.'

${ }^{18}$ Quoted by Ulvi Olgac (1939: 60) in Guzel Izmir ne idi? Ne oldu? (Beautiful Izmir, what was it? What did it become?), Izmir - The quote was found in Bilsel (1996: 348) and translated by the author from French.

${ }^{19}$ Wright (1991: 73) talks about the differences between politics of assimilation and association, and how these relate to "two contemporaneous variations of modernism in architecture and urban design - a more avant-garde or universalist version and a more traditionalist or cultural-relativist approach'.

20 That is, despite the unquestionable relation between the two, and the importance of the colonial cities as 'laboratories', to use Çelik's (1992) and Wright's (1991) words, for planning at home.

${ }^{21}$ The theory of continuity was advocated most notably by Constantine Paparrigopoulos (1815-1891) who is considered the founder of modern Greek historiography, and the national historian of modern Greece. According to his multi-volume History of the Greek Nation, Greek history can be divided into three periods: ancient Hellenism, medieval Hellenism
(Byzantine era) and modern Hellenism (Greek Kingdom).

22 'I accept as correct and logical the demolition of the minarets of former Christian churches which had been turned into mosques. But the demolition of the minarets of other mosques is a coarse act stemming from mindless chauvinism. Those issuing the decree imagined that they could thus make the traces of Turkish occupation disappear. But history is not written with the destruction of innocent monuments which beautified the city' [...] The disappearance of the traces of the occupation should come about only through the elevation of our own civilization' (Yerolympos, 1995).

\section{References}

Akçan, E 2012 Architecture in Translation: Germany, Turkey and the Modern House. Durham: Duke University Press. DOI: http://dx.doi.org/10.1215/ 9780822395577

Akpinar, I 2003 The Rebuilding of Istanbul after the Plan of Henri Prost 1937-1960: from Secularization to Turkish Modernization. Unpublished Thesis (PhD), Bartlett School of Graduate Studies, UCL.

Baran, T A 2009 Bir Kentin Yeniden Yapulanmast - Izmir 1923-1938. Istanbul: Arma Yayınları.

Bilsel, C 1996 Cultures et Fonctionnalites: L'Evolution de la Morphologie Urbaine de la Ville d'Izmir aux XIXe et debut Xxe siècles. Unpublished Thesis ( $\mathrm{PhD}), \mathrm{Sci}-$ ence Sociales et Administration, Universite de Paris X Nanterre.

Bozdoğan, S 2001 Modernism and Nation Building: Turkish Architectural Culture in the Early Republic. Seattle: University of Washington Press.

Çelik, Z 1992 Le Corbusier, Orientalism, Colonialism. Assemblage 17 (April 1992): pp. 58-77. DOI: http://dx.doi. org/10.2307/3171225

Danger, R 1947 Cours d'Urbanisme, Paris: Editions Eyrolles. 
Davis, J L 2000 Warriors for the Fatherland: National Consciousness and Archaeology in 'Barbarian' Epirus and 'Verdant' Ionia 1912-1922. Journal of Mediterranean Archaeology, 13(1): pp. 76-98. DOI: http://dx.doi.org/10.1558/jmea. v13i1.76

Davis, J L 2003 A Foreign School of Arcaheology and the Politics of Archaeological Practice: Anatolia, 1922. Journal of Mediterranean Archaeology, 16(2): 145-172.

Güven, C 2006 Milli Mücadele Döneminde Fransiz Gazeteci ve Yazar Berthe Georges Gaulis'in Mustafa Kemal Paşa ile Temas ve Görüşmeleri. SÜ Sosyal Bilimler Ensitüsü Dergisi, 16: 353-365.

Hastaoglu-Martinidis, V 2011 Urban Aesthetics and National Identity: the Refashioning of Eastern Mediterranean Cities between 1900 and 1940. Planning Perspectives, 26(2): 153-182. DOI: http:// dx.doi.org/10.1080/02665433.2011.550 442

Hautecoeur, L 1960 Henri Prost a la Villa Médicis (1902-1907). In: L'Oeuvre d'Henri Prost. Paris: Academie d'Architecture, Imprimerie du Compagnonnage, pp. 11-30.

Isenstadt, S and Rizvi, K 2008 Modernism and the Middle East: architecture and politics in the twentieth century. Seattle: University of Washington press.

Kolluoglu Kırli, B 2007 Cityscapes and Modernity: Smyrna Morphing into Izmir, in Frangoudaki, A and Keyder, C (eds) 2007 Ways to Modernity in Greece and Turkey. London: Tauris, pp. 218

Kolonas, V 2012 I Arhitektoniki mias Ekatontaetias: Thessaloniki 1912-2012. Thessaloniki: University Studio Press.

Lavedan, P 1921 Un Probleme d'Urbanisme: La Reconstruction de Salonique. Gazette des Beaux-Arts, 64, Septembre-Octobre 1921, pp. 231-248.

Lavedan, P 1933 L 'CEuvre d'Ernest Hébrard en Grèce. Urbanisme, 14 May 1933, pp 148-162.

Lemes, F 2010 The First Town Planning Conference Revisited (1910-2010). Unpublished proceedings of The 14th International Planning History Society (IPHS) Conference, Istanbul, Turkey on 12-15 July 2010, pp. 1-12.

Mazower, M 2004 Salonica, City of Ghosts: Christians, Muslims and Jews- 1430-1950. New York: HarperCollins.

Olgaç, U 1939 Güzel Izmir ne idi? Ne oldu? Izmir: Meşher Basımevi.

Pinon, P and Bilsel, C (eds.) 2010 From the Imperial Capital to the Republican Modern City: Henri Prost's Planning of Istanbul (1936-1951). Istanbul: Istanbul Arastirmaları Enstitusu.

Stamatopoulos, D 2009 To Vyzantion meta to Ethnos: To Problima tis Syneheias stis Balkanikes Istoriografies. Athens: Alexandreia.

Wright, G 1991 The Politics of Design in French Colonial Urbanism. Chicago and London: The University of Chicago Press.

Wright, G and Rabinow, P 1982 Savoir et Pouvoir dans l'Urbanisme Moderne Colonial d'Ernest Hébrard. Cahiers de la Recherche Architecturale, No 9 (January 1982), Paris, pp. 36-38.

Yerolympos, A 1995 I Anoikodomisi tis Thessalonikis meta tin Pyrkagia tou 1917, 2nd ed. Thessaloniki: University Studio Press.

Yerolympos, A 1996 Urban Transformations in the Balkans (1820-1920), 1st ed. Thessaloniki: University Studio Press.

Yerolympos, A 2013 I Anadisi tis Sighronis Thessalonikis. Thessaloniki: University Studio Press. 
How to cite this article: Amygdalou, K 2014 Building the Nation at the Crossroads of 'East' and 'West': Ernest Hébrard and Henri Prost in the near East. Opticon1826, (16): 15, pp.1-19, DOl: http:// dx.doi.org/10.5334/opt.bv

Published: 15 October 2014

Copyright: ( 2014 The Author(s). This is an open-access article distributed under the terms of the Creative Commons Attribution 3.0 Unported License (CC-BY 3.0), which permits unrestricted use, distribution, and reproduction in any medium, provided the original author and source are credited. See http://creativecommons.org/licenses/by/3.0/. ] $\mathrm{u}\left[\begin{array}{l}\text { Opticon1826 is a peer-reviewed open access journal published by } \\ \text { Ubiquity Press }\end{array}\right.$ 